ACTA MYCOLOGICA

Vol. 42 (2): 267-280

2007
It is our great pleasure and honour

to dedicate this paper to active and untiring

Professor Alina Skirgietto

on the occasion of her anniversary

\title{
New lichen records from Bukovské vrchy Mts (NE Slovakia)
}

\author{
IVAN PIŠÚT, ${ }^{1}$ ANNA LACKOVIČOVÁ ${ }^{1}$, ANNA GUTTOVÁ ${ }^{1}$ and ZDENĚK PALICE ${ }^{2,3}$
}

\author{
${ }^{1}$ Institute of Botany, Slovak Academy of Sciences, Dúbravská cesta 14 \\ SK-845 23 Bratislava, anna.lackovicova@savba.sk \\ ${ }^{2}$ Institute of Botany, Academy of Sciences of the Czech Republic \\ CZ-252 43 Průhonice, palice@ibot.as.cz \\ ${ }^{3}$ Department of Botany, Faculty of Natural Sciences \\ Charles University, Benátská 2, CZ-128 01 Praha 2
}

Pišút I., Lackovičová A., Gut tová A., Palice Z.: New lichen records from Bukovské vrchy Mts (NE Slovakia). Acta Mycol. 42 (2): 267-280, 2007.

Interesting findings of 100 lichens from the Bukovské vrchy Mts (Biosphere Reserve Poloniny, Slovak part) are reported as the result of recent survey work. Two species are new for Slovakia: Fellhanera gyrophorica and Rinodina efflorescens, and 34 species are reported for the first time from the studied area. The new records for the country are shortly commented as well as ecological aspects of Agonimia repleta, Strigula stigmatella, Gyalecta ulmi and Belonia herculina.

Key words: lichenized fungi, biodiversity, biosphere reserve, Poloniny, Eastern Carpathians

\section{INTRODUCTION}

Bukovské vrchy Mts comprising about $690 \mathrm{~km}^{2}$ and to a great extant overlapping with the territory of the National Park Poloniny, span the north-eastern tail of Slovakia. The mountains unlike the majority of the country already belong to the Eastern Carpathians. Eastern boundary coincides with the borderline of Slovakia and Ukraine as far as the Kremenec Mt. (1208 m a.s.l.), a meeting point of three countries confines - Slovakia, Poland and Ukraine. Polish state borderline from Kremenec Mt. to the spring areas of the river Udava delimit the area in the north.

Bukovské vrchy Mts are built of flysch, claystones and sandstones, which is reflected in the shape of the landscape. The mountains along the border of Slovakia and Poland range from $797 \mathrm{~m}$ a.s.l. to $1208 \mathrm{~m}$ a.s.l., the Slovak - Ukrainian ridge is dominated by Stinská Mt. (1092 m a.s.l.) and Kalnica Mt. (1004 m a.s.l.). The highest point inside the region is Vel'ký Bukovec Mt. (1012 m a.s.l.).

The area boasts of substantial, non-fragmented cover of beech forests, in higher altitudes and north expositions altered by beech-fir forests of pristine character. South slopes are lined with oak-beech forests. The most significant, also on 
international level, is the old-growth forest Stužica, which spreads over the valley of the Stužická rieka.

The mountains fall within Unesco Biosphere Reserve Poloniny being the only trilateral reserve, unfolding on the area of three countries - Poland, Ukraine and Slovakia. Lichen diversity of Polish part comprises up to 600 species (Kis zk a 1997, 1999; Kiszka, Kościelniak 1998, 2001). Recent lists of lichens from Ukrainian part include almost 430 taxa (Coppins et al. 1998, 2005).

The lichens in the Slovak area, were explored for the first time only in 1931 and 1932, when Josef Nádvorník, a teacher in the „Zakarpatska oblast“, visited the place Riaba skala during one-day excursions (e.g. Se rvít, Nádvorník 1935). After three decades the mountains were revisited by Ivan Pišút (Pišút 1964, 1966), later by Jiří Liška (Lišk a 1980). In 1989 Ivan Pišút and Anna Lackovičová started contemporary and targetted research here, later Anna Guttová and Zdeněk Palice joined them. Part of the results were already published (e.g. Pišút, Lackovičová 1992; Pišút 1995; Guttová 1997; Lackovičová 1998; Lackovičová, Guttová 2006), further taxa were included in the Checklist of Eastern Carpathian lichens without localities (Kond ratyuk et al. 2003). In total, almost 300 species were recorded here. The number of species reflects also the size of the area of Poloniny in Slovakia (out of the three parts is the smallest one) and smaller diversity of substrata.

\section{MATERIAL AND METHODS}

The most interesting results of lichenological research conducted in 1989-1994 and 2002-2004 in the territory of Bukovské vrchy Mts are presented. The specimens are kept in the collection of the Institute of Botany, Academy of Sciences of the Czech Republic, Průhonice (PRA) and of the Institute of Botany, Slovak Academy of Sciences, Bratislava (specimens without reference to the herbarium).

Abbreviations: !! - species new for Slovakia; ! - species new for the Bukovské vrchy Mts; NNR - National Nature Reserve; NR - Nature Reserve; AG - Anna Guttová; AL - Anna Lackovičová; IP - Ivan Pišút; ZP - Zdeněk Palice; Aa - Abies alba, Acc - Acer campestre, Acpl-A. platanoides, Acps - A. pseudoplatanus, Al-Alnus sp., Alg-Alnus glutinosa, Ali-A. incana, $B$ - Betula sp., Cb - Carpinus betulus, Fr - Fraxinus sp., Fre - F. excelsior, Fs - Fagus sylvatica, Jr - Juglans regia, Md - Malus domestica, Po - Populus sp., P - Pinus sp., Pyc - Pyrus communis, $Q-Q u e r c u s$ sp., $S$ - Salix sp., T- Tilia sp., Tc - T. cordata, Tp - T. platyphyllos, Ulg - Ulmus glabra.

\section{RESULTS AND DISCUSSION}

\section{LIST OF SPECIES}

\section{!Absconditella delutula (Nyl.) Coppins \& H. Kilias}

SPECIMENS EXAMINED: The valley of the Zbojský potok stream: upwards Nová Sedlica village, upstream, a stump, 640 m, 2002, leg. $A L \& A G$; Uličská kotlina basin: Uličské Krivé village, managed beech forest ca $2 \mathrm{~km}$ E, N48 59'15-25”/E22 $28^{\circ}$, sandstone pebbles, 500-550 m, 2002, leg. AG, AL\& ZP (PRA). 


\section{:Agonimia repleta Czarnota \& Coppins}

SPECIMENS EXAMINED: Uličská kotlina basin: Uličské Krivé village, managed beech

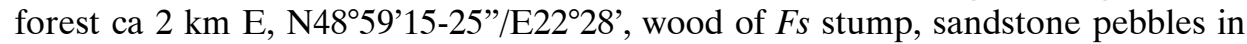
ditch of forest road, 500-550 m, 2002, leg. $A G, A L \& Z P$ (PRA).

:Anisomeridium polypori (M.B. Ellis \& Everh.) M.E. Barr

SPECIMENS EXAMINED: NNR Pl'aša: WNW slope, deciduous forest in a spring area, N49 $06^{\circ} 90^{\prime \prime} / \mathrm{E} 22^{\circ} 23.85^{`}, F s, 1127$ m, 2004, leg. ZP (PRA); NNR Stužica: fir-beech forest in the valley of Stužická rieka, N49 04'30-45"/E22 $31^{\prime} 20^{\prime \prime}-22^{\circ} 32^{\prime}$, exposed root of $F s, 700-740$ m, 2002, leg. $A G \& Z P$ (PRA); Part Javorník: NNR Rožok (SE of Uličské Krivé village), sandstone pebbles in ditch of forestry-road, Javorník - a crest NE of nature reserve, N48 58'50-55"/E22²8'30", Fre, $750 \mathrm{~m}$, 2002, leg. $A G, A L \& Z P$ (PRA); Sedlická kotlina basin: road between the villages Zboj and Nová Sedlica, a crucifix, $380 \mathrm{~m}$, Fre, 2002, leg. $A G \& A L$.

\section{:Arthonia spadicea Leight.}

SPECIMEN EXAMINED: Uličská kotlina basin: Uličské Krivé village, old-growth beech forest ca $2.5 \mathrm{~km}$ E, N48 59'15-25”/E22²8'10-15”, Fs, 570-620 m, 2002, leg. $A G, A L \& Z P$ (PRA).

\section{'Arthonia vinosa Leight.}

SPECIMEN EXAMINED: The valley of the Zbojský potok stream: upwards Nová Sedlica village, the section between the junction to Rabia skala Mt. and gamekeeper's house, $F r, 700-800 \mathrm{~m}, 2002$, leg. $A G \& A L$.

Bacidia bagliettoana (A. Massal. \& De Not.) Jatta

SPECIMEN EXAMINED: Oreničova skala place (S of NNR Pl'aša): bryophytes over sandstone rocks, $710 \mathrm{~m}, 1994$, leg. IP.

Bacidia biatorina (Körb.) Vain.

SpeCimen EXAmined: The valley of the Zbojský potok stream: upwards Nová Sedlica village, upstream, $F s, 700 \mathrm{~m}, 2003$, leg. $A G \& A L$.

!Bacidia circumspecta (Nyl. ex Vain.) Malme

SPECIMEN EXAMINED: NNR Stužica: fir-beech forest in the valley of Stužická rieka, N4904'30-45"/E22³1'20"-22³2', Fs, 700-740 m, 2002, leg. AG \& ZP (PRA).

\section{Bacidia fraxinea Lönnr.}

SPECIMENS EXAMINED: Abandoned village Ostrožnica ( $\mathrm{N}$ of Starina water reservoir): $T, 400 \mathrm{~m}, 1994$, leg. $A L \& I P$; Ruská kotlina basin: abandoned village Zvala, Fre, 480 m, 1994, leg. AL \& IP; ibid., abandoned village Ruské, 480 m, 1994, leg. $A L$ $\& I P$; the valley of the Zbojský potok stream: upwards Nová Sedlica village, the meadow „Lúka Medovej baby“, young ash grow on alluvium, $F, 550$ m, 2003, leg. $A G \& A L$.

!Bacidia incompta (Borrer ex Hook.) Anzi

SPECIMEN EXAMINED: NNR Stužica: fir-beech forest in the valley of Stužická rieka, N4904'30-45"/E22³1'20"-22³2', wood of Acps, 700-740 m, 2002, leg. AG \& ZP (PRA).

Bacidia rubella (Hoffm.) A. Massal.

SPECIMENS EXAMined: Ruská kotlina basin: abandoned village Zvala, Fre, $480 \mathrm{~m}$, 1994, leg. $A L \&$ \& ; NR Uličská Ostrá: the valley of the Ulička river between the villages Ulič and Kolbasov, $Q, 350 \mathrm{~m}, 1993$, leg. IP; the valley of the Zbojský potok 
stream: upwards Nová Sedlica village, SW slope of the elevation point Jaseniny (606.0), Acps, 500 m, 2002, leg. $A L \& A G$.

!Bacidia subincompta (Nyl.) Arnold

SPECIMENS EXAMINED: NNR Stužica: the valley of the stream Stužická rieka, mixed primeval forest, $F s, 700-740 \mathrm{~m}, 2002$, leg. $A G \& Z P$; Topol'a village (in the Ulička river valley): SE foot of the hill Lesík (elevation point 580), hornbeam-lime forest on a steep slope at crossroads Topol'a-Príslop-Kolbasov, N49 01.70'/E22 $21.15^{\prime}, C b$, 380-400 m, 2004, leg. ZP \& J. Šárová (PRA).

Bacidina inundata (Fr.) Vězda

Specimen eXAmined: Pl'aša Mt.: SW bottom in the valley of the Ruský potok stream, temporary sumberged pebbles in the stream, $900 \mathrm{~m}, 1992$, leg. $A L \& I P$.

Belonia herculina (Rehm ex Lojka) Hazsl.

SPecimens EXAmined: NNR Pl'aša: SW slope, $F$ s by the stream, $870 \mathrm{~m}, 1992$, leg. $A L \& I P$; Part Javorník: NNR Rožok (SE of Uličské Krivé village), upper part, 650$700 \mathrm{~m}, F s$, 2002, leg. $A G, A L \& Z P$; NNR Stužica: fir-beech forest in steep slope, N4904'15-20"/E22 32'15-20", Fs, 750-800 m, 2002, leg. $A G \&$ \&P (PRA); ibid., fir-

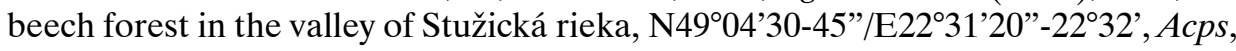
Fs, 700-740 m, 2002, leg. $A G \& Z P$ (PRA); ibid., well-lit beech forest below the main crest, between points Ciert'až and Hrúbky, N49 05’30"/E22 31'30”, Fs, 1050-1100 m, 2002, leg. $A G \& Z P$ (PRA); Packova Kýčera Mt.: WSW-W slope (N of Nová

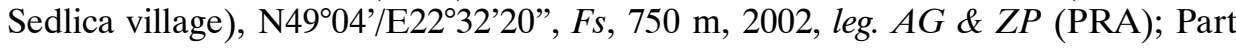
Javorník: NNR Rožok (SE of Uličské Krivé village), uppermost part of old-growth beech forest, N48 $58^{\prime} 45^{\prime \prime} / \mathrm{E} 22^{\circ} 28^{\prime} 10-15^{\prime \prime}, F s, 600-640 \mathrm{~m}, 2002$, leg. $A G, A L \& Z P$ (PRA).

!Biatora chrysantha (Zahlbr.) Printzen

SPECIMENS EXAMINED: NNR Pl'aša: WNW slope, deciduous forest in a spring area, N4906.90'/E22²3.85', Acps, Fs, 1127 m, 2004, leg. ZP (PRA); NNR Stužica: fir-

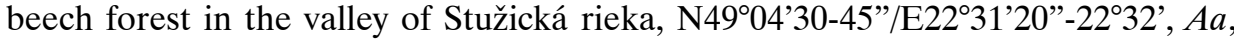
700-740 m, 2002, leg. $A G \& Z P$ (PRA); Part Javorník: NNR Rožok (SE of Uličské Krivé village), lowermost part, old-growth beech forest, N48 58'50-55"/E22 27'3540", over mosses on Fs trunk, 470-480 m, 2002, leg. $A G, A L \& Z P$ (PRA).

!Biatora efflorescens (Hedl.) Räsänen

SPECIMEN EXAMINED: NNR Pl'aša: WNW slope, deciduous forest in a spring area, N4906.90'/E22²3.85', Fs, 1127 m, 2004, leg. ZP (PRA).

Biatora globulosa (Flörke) Fr. [= Bacidia globulosa, sec. Printzen 2004]

SPECIMENS EXAmINED: NNR Jarabá skala: Riaba skala Mt., S slope, Acps, $1100 \mathrm{~m}$, 1992, leg. $A L \& I P$; ibid., the ridge, Acps, $1150 \mathrm{~m}, 1992$, leg. IP; the valley of the Zbojský potok stream: upwards Nová Sedlica village, a pond, $U l g$, the bark of the pond, $620 \mathrm{~m}, 2002$, leg. $A G \& A L$; ibid., a clearing Skoňová, $Q, 500 \mathrm{~m}, 2003$, leg. $A G \& A L$; Part Javorník: the summit of the border ridge between Prípor Mt. and NNR Rožok (SE of Uličské Krivé village), around the border stone no 74, Acps, 780 m, 2002, leg. $A G, A L \& Z P$.

Biatora vernalis (L.) Fr.

SPECIMEN EXAMINED: NNR Stužica: fir-beech forest in the valley of Stužická rieka, N4904'30-45"/E22³1'20"-2232', Fs, 700-740 m, 2002, leg. AG \& ZP (PRA). 
!Biatoridium monasteriense J. Lahm ex Körb.

SPECIMEN EXAMINED: NNR Stužica: fir-beech forest in the valley of Stužická rieka, N4904'30-45"'E22³1'20"'-22³2', Fs, 700-740 m, 2002, leg. AG \& ZP (PRA).

Calicium glaucellum Ach.

Specimen EXAMINED: NR Udava: SW periphery, $A a$ (rotten trunk), 650 m, 1994, leg. IP.

Calicium salicinum Pers.

SPECIMEN EXAMINED: NR Udava: SW periphery, $A a$ (rotten trunk), 650 m, 1994, leg. IP.

Caloplaca decipiens (Arnold) Blomb. \& Forssell

SPECIMEN EXAMINED: Sedlická kotlina basin: Nová Sedlica village, concrete wall, $430 \mathrm{~m}, 1992$, leg. AL \& IP.

Caloplaca herbidella (Hue) H. Magn.

SPECIMEN EXAMINED: The valley of the Zbojský potok stream: upwards Nová Sedlica village, $F r, 700-800 \mathrm{~m}, 2002$, leg. $A G \& A L$.

!Catillaria alba Coppins \& Vězda

SPECIMEN EXAmineD: NNR Stužica: Kremenec Mt., SW slope, fir-beech forest, N4905'/ E22³3'15”, wood of $A a, 960-980$ m, 2004, leg. ZP \& J. Šárová (PRA).

Chaenotheca chrysocephala (Ach.) Th. Fr.

SPECIMENS EXAMINED: NR Udava: SW periphery, $A a$ (rotten stump) - $610 \mathrm{~m}, A a$ - 630 m, 1994, leg. AL \& IP; Abandoned village Ostrožnica (N of Starina water reservoir): wood, $400 \mathrm{~m}, 1994$, leg. $A L \& I P$.

Chaenotheca furfuracea (L.) Tibell

SPECIMEN EXAMINED: NR Udava: SW periphery, $A a$ (rotten trunk), 610 m, 1994, leg. $A L \& I P$.

Cladonia arbuscula (Wallr.) Flot. subsp. mitis (Sandst.) Ruoss

SPECIMENS EXAMINED: Ruská kotlina basin: arenaceous soil below Ruské sedlo mountain pass $\mathrm{N}$ of the abandoned Ruské village, $600 \mathrm{~m}, 1992$, leg. AL \& IP; ibid., abandoned village Ruské, the hill S of the Ruský potok river, arenaceous soil, 550 m, 1994, leg. AL \& IP.

Cladonia cariosa (Ach.) Spreng.

SPECIMENS EXAMINED: Ruská kotlina basin: below Ruské sedlo mountain pass $\mathrm{N}$ of the abandoned Ruské village, arenaceous soil, $600 \mathrm{~m}, 1992$, leg. AL \& IP; ibid., the valley of the Ruský potok stream, arenaceous soil, $650 \mathrm{~m}, 1992$, leg. AL \& IP.

Cladonia phyllophora Hoffm.

SPECIMEN EXAMINED: Ruská kotlina basin: abandoned village Ruské, the hill S of the Ruský potok river, arenaceous soil, 550 m, 1994, leg. AL \& IP.

Cladonia polycarpoides Nyl.

SPECIMENS EXAMINED: Ruská kotlina basin: abandoned village Ruské, the hill S of the Ruský potok river, arenaceous soil, 550 m, 1994, leg. AL \& IP; Runianska kotlina basin: Runina village, grasslands above the village, bare soil, $620 \mathrm{~m}, 2002$, leg. $A L \&$ $A G$; Sedlická kotlina basin: Nová Sedlica village, N4903'15-20”/E22³1'10”, in ditch at roadside near the field station of NP Poloniny, on sandy soil, $450 \mathrm{~m}, 2002$, leg. ZP (PRA). 
!Cladonia ramulosa (With.) J.R. Laundon

SPECIMEN EXAMINED: NNR Šípková: Šipková Mt., the ridge, Fs, 1000 m, 1992, leg. IP.

Cladonia rangiferina (L.) Weber ex F.H. Wigg.

SPECIMEN EXAMINED: NNR Stužica: Kamenná lúka Mt., on soil among Vaccinum myrtillus, 1200 m, 2003, leg. AG.

Cladonia rangiformis Hoffm.

SPECIMEN EXAMINED: Ruská kotlina basin: below Ruské sedlo mountain pass $\mathrm{N}$ of the abandoned Ruské village, arenaceous soil, 600 m, 1992, leg. IP.

Cladonia rei Schaer.

SPECIMEN EXAMINED: Sedlická kotlina basin: Nová Sedlica village, N part, open slopes ca $50 \mathrm{~m}$ from the field station of NP Poloniny, on soil, $450 \mathrm{~m}, 2002$, leg. AG.

Cladonia symphycarpia (Flörke) Fr.

SPECIMENS EXAMINED: Ruská kotlina basin: the valley of the Ruský potok stream, sandstone rocks, 515 m, 1994, leg. AL \& IP; ibid., abandoned village Ruské, the hill S of the Ruský potok river, arenaceous soil, $550 \mathrm{~m}, 1994$, leg. AL \& IP.

Cladonia verticillata (Hoffm.) Schaer.

SPECIMEN EXAMINED: Ruská kotlina basin: abandoned village Ruské, the hill $\mathrm{S}$ of the Ruský potok river, arenaceous soil, $550 \mathrm{~m}, 1994$, leg. AL \& IP.

Collema auriforme (With.) Coppins \& J.R. Laundon

SPECIMEN EXAMINED: Ruská kotlina basin: the valley of the Ruský potok stream, on the foot of the Pl'aša hill, 750 m, over bryophytes on sandstone rocks, 1992, leg. $A L \& I P$.

Collema fuscovirens (With.) J.R. Laundon

SPECIMEN EXAMINED: NNR Jarabá skala: Riaba skala Mt., S slope, fissures of sandstone rocks, $1130 \mathrm{~m}, 1992$, leg. IP.

Dermatocarpon leptophyllum (Ach.) K.G.W. Lång

SPECIMEN EXAMINED: NNR Jarabá skala: Riaba skala Mt., S slope, arenaceous rocks, $1130 \mathrm{~m}$, 1992, leg. IP.

Note. The species is drafted in the Checklist of lichens of Slovakia (Pišút et al. 1996, 1998) based on Poelt's report from the Vysoké Tatry Mts (Poelt 1962, 1969). His information was, however, general, since he did not mentioned specific locality. The entry from Bukovské vrchy Mts is the first confirmed information on the occurrence of this rare species in Slovakia.

Dermatocarpon luridum (With.) J.R. Laundon

SPECIMEN EXAMINED: NNR Jarabá skala: Riaba skala Mt., S slope, temporary inundated sandstone rocks, $1130 \mathrm{~m}, 1992$ leg. IP.

!Dermatocarpon miniatum (L.) W. Mann

SPECIMEN EXAMINED: NR Šípková: sandstone rock bellow the top, 980 m, 1992, leg. IP.

!Diplotomma epipolium (Ach.) Arnold

SPECIMEN EXAMINED: NNR Jarabá skala: Riaba skala Mt., S slope, sandstone rocks, $1130 \mathrm{~m}$, 1992, leg. IP. 
!!Fellhanera gyrophorica Sérus., Coppins, Diederich \& Scheideg.

SPECIMEN EXAMINED: NNR Stužica: fir-beech forest in the valley of Stužická rieka, N49 04'30-45"/E22 31'20"'-22³2', on Fs over bryophytes and on bark directly, 700740 m, 2002, leg. $A G \& Z P$ (PRA).

Fuscidea fagicola (Zschacke) Hafellner \& Türk $[=$ F. cyathoides var. corticola (Fr.) Kalb, sec. Hafellner \& Türk 2001]

SPECIMEN EXAMINED: NNR Stužica: beech forest on the crest Čiert'až-HrúbkyKremenec, N4905.57’/E22³1.56', Fs, 1110 m, 2004, leg. ZP \& J. Šárová (PRA).

Gyalecta jenensis (Batsch) Zahlbr.

SPECIMENS EXAMINED: NR Š́pková: between the pass Sedlo pod Šípkovou and the village Ruské, sandstone rock, 850 m, 1992, leg. AL \& IP; NNR Pl'aša: Pl'aša Mt., SW slope, place called „Pod alpínkou“, sandstone, 750 m, 1992, leg. AL \& IP.

Gyalecta flotowii Körb.

SPECIMENSEXAMINED:NNRStužica:fir-beechforestinsteepslope above theStužická rieka, N4904'15-20"'E22³2'15-20", Fs, 750-800 m, 2002, leg. AG \& ZP (PRA); ibid., fir-beech forest in the valley of Stužická rieka, N4904'30-45'/E22³1'20”-2232', Fs, 700-740 m, 2002, leg. $A G$ \& ZP (PRA).

Gyalecta ulmi (Sw.) Zahlbr.

SPECIMEN EXAMINED: Topol'a village (in the Ulička river valley): SE foot of the hill Lesík (elevation point 580), hornbeam-lime forest on a steep slope at crossroads Topol'a-Príslop-Kolbasov, N4901.70'/E22 $21.15^{\circ}$, on dead bryophytes on sandstone boulder, 380-400 m, 2004, leg. ZP \& J. Šárová (PRA).

Haematomma ochroleucum (Neck.) J.R. Laundon

SPECIMEN EXAMINED: The valley of the Zbojský potok stream: upwards Nová Sedlica village, S-W slope of the elevation point Jaseniny (606.0), Acps, 500-580 m, 2002, leg. $A L \& A G$.

!Hypocenomyce caradocensis (Leight. ex Nyl.) P. James \& Gotth. Schneid.

SPECIMEN EXAMINED: The valley of the Zbojský potok stream: upwards Nová Sedlica village, beech-fir forest at the foot of Rabia skala, $A a, 900 \mathrm{~m}, 2002, \operatorname{leg} . A G \&$ AL.

Imshaugia aleurites (Ach.) S.L.F. Meyer

SPECIMEN EXAMINED: Uličská kotlina basin: park in the Ulič village, dry trunk of $P, 315 \mathrm{~m}, 1993$, leg. AL \& IP.

Ionaspis ceracea (Arnold) Hafellner \& Türk

SPECIMEN EXAMINED: Sedlická kotlina basin: Nová Sedlica village, N4903'15-20”/ E22 31 '10", in ditch at roadside near the field station of NP Poloniny, on sandstone pebbles, $450 \mathrm{~m}, 2002$, leg. ZP (PRA).

Lecanactis latebrarum (Ach.) Arnold

SPECIMEN EXAMINED: Oreničova skala place (S of NNR Pl'aša): sandstone rocks, 710 m, 1994, leg. AL \& IP.

Lecanora albella (Pers.) Ach.

SPECIMEN EXAMINED: The valley of the Zbojský potok stream: upwards Nová Sedlica village, downstream, $A$ lg, 450-480 m, 2002, leg. $A L \& A G$. 
!Lecanora strobilina (Spreng.) Kieff.

SPECIMEN EXAMINED: Topol'a village (in the Ulička river valley): SE foot of the hill Lesík (elevation point 580), hornbeam-lime forest on a steep slope at crossroads Topol'a-Príslop-Kolbasov, N4901.70'/E22²1.15', Cb, 380-400 m, 2004, leg. ZP \& J. Šárová (PRA).

\section{Lecanora subcarpinea Szatala}

SPECIMEN EXAmineD: Topol'a village (in the Ulička river valley): SE foot of the hill Lesík (elevation point 580), hornbeam-lime forest on a steep slope at crossroads Topol'a-Príslop-Kolbasov, N4901.70'/E22²1.15', Cb, 380-400 m, 2004, leg. ZP \& J. Š́rová (PRA).

\section{Lecanora subrugosa Nyl.}

SPECIMEN EXAMINED: The valley of the Zbojský potok stream: upwards Nová Sedlica village, SW slope of the elevation point Jaseniny (606.0), Acps, 500 m, 2002, leg. $A L \& A G$.

\section{Lecidea pullata (Norman) Th. Fr.}

SPECIMEN EXAMINED: NNR Stužica: Hrúbky Mt., $F s$ on the ridge, 1170 m, 1989, leg. IP, det. $V$. Wirth.

!Lepraria rigidula (de Lesd.) Tønsberg

SPECIMEN EXAMINED: NNR Stužica: beech forest on the crest Čiert'až-HrúbkyKremenec, N4905.57'/E22³1.56', Fs, 1110 m, 2004, leg. ZP \& J. Šárová (PRA).

Lobaria pulmonaria (L.) Hoffm.

SPECIMENS EXAMINED: The valley of the Zbojský potok stream: upwards Nová Sedlica village, NW foot of the elevation Konský hrb (682.3), Acps, 500-550 m, 2002, leg. $A L \& A G$; ibid., elevation point Jaseniny (606.0), S-W slope, Acps, 500-580 m, 2002, leg. $A L \& A G$.

Melanohalea elegantula (Zahlbr.) O. Blanco, A. Crespo, Divakar, Essl., D. Hawksw. \& Lumbsch

SPECIMENS EXAMINED: Osadné village: gamekeeper's lodge in the valley of the Udava river NE of the village, $T c, 550 \mathrm{~m}$, 1994, leg. AL \& IP; Príslop village (in the Ulička river valley): Tp, $380 \mathrm{~m}, 1993$, leg. IP.

Melanohalea laciniatula (H. Olivier) O. Blanco, A. Crespo, Essl., D. Hawksw. \& Lumbsch

SPECIMEN EXAMINED: Osadné village: gamekeeper's lodge in the valley of the Udava river NE of the village, $T c, 550 \mathrm{~m}, 1994$, leg. AL \& IP.

Menegazzia terebrata (Hoffm.) A. Massal.

Specimen EXAmined: The valley of the Zbojský potok stream: upwards Nová Sedlica village, SW slope of the elevation point Jaseniny (606.0), Acps, 500 m, 2002, leg. $A L \& A G$.

!Micarea erratica (Körb.) Hertel, Rambold \& Pietschm.

SPECIMEN EXAmINED: Sedlická kotlina basin: Nová Sedlica village, N4903'15-20”/ E22 $31 ' 10 "$, in ditch at roadside near the field station of NP Poloniny, on sandstone pebbles, $450 \mathrm{~m}$, 2002, leg. ZP (PRA). 
!Micarea lithinella (Nyl.) Hedl.

SPECIMENS EXAMINED: Sedlická kotlina basin: Nová Sedlica village, N4903'15-20”/ E22 31 '10", in ditch at roadside near the field station of NP Poloniny, on sandstone pebbles, 450 m, 2002, leg. ZP (PRA); Part Javorník: NNR Rožok (SE of Uličské Krivé village), a crest NE of the reserve, N48 $58^{\prime} 50-55^{\prime \prime} / \mathrm{E} 22^{\circ} 28^{\prime} 30^{\prime \prime}$, sandstone pebble, $750 \mathrm{~m}$, 2002, leg. $A G, A L \& Z P$ (PRA).

!Mycobilimbia pilularis (Körb.) Hafellner \& Türk

SPECIMEN EXAMINED: Oreničova skala place (S of NNR Pl'aša): bryophytes over sandstone rocks, $710 \mathrm{~m}$, 1994, leg. IP.

Mycobilimbia tetramera (De Not.) Vitik., Ahti, Kuusinen, Lommi \& T. Ulvinen

SPECIMEN EXAMINED: NNR Stužica: fir-beech forest in the valley of Stužická rieka, N4904'30-45"/E22³1'20"-2232', Fs, 700-740 m, 2002, leg. AG \& ZP (PRA).

Ochrolechia androgyna (Hoffm.) Arnold

SPecimens EXAmined: NNR Pl'aša: Pl'aša Mt., SW slope, $F s, 930$ m, 1992, leg. $A L$ \& IP; ibid., ridge below the summit, $F s, 1100 \mathrm{~m}, 1992$, leg. $A L \& I P$; NNR Jarabá skala: Riaba skala Mt., S slope, $A a, 950 \mathrm{~m}, 1992$, leg. $A L \& I P$; NR Udava: SW periphery, $A a$ (rotten stump), $610 \mathrm{~m}, 1994$, leg. $A L \& I P$.

Opegrapha varia Pers.

SPECIMENS EXAMINED: NNR Jarabá skala: Riaba skala Mt., below the ridge, $A c p l$, Fs, 900 m, 1992, leg. AL \& IP; ibid., the ridge, Ulg, 980 m, 1992, leg. IP; NNR Stužica: fir-beech forest in the valley of Stužická rieka, N49 $04^{\prime} 30-45^{\prime \prime} / \mathrm{E} 22^{\circ} 31^{\prime} 20^{\prime \prime}-22^{\circ} 32^{\prime}$, Fs, 700-740 m, 2002, leg. $A G \& Z P$ (PRA); the valley of the Zbojský potok stream: upwards Nová Sedlica village, SW-W slope of the elevation Jaseniny (606.0), Acps, 500-580 m, 2002, leg. $A L \& A G$.

!Opegrapha vermicellifera (Kunze) J.R. Laundon

SPECIMEN EXAMINED: NNR Stužica: fir-beech forest in the valley of Stužická rieka, N4904'30-45"/E22³1'20"-22³2', Acps, 700-740 m, 2002, leg. AG \& ZP (PRA).

!Opegrapha viridis (Pers. ex Ach.) Behlen \& Desberger

SPECIMENS EXAMined: Part Javorník: NNR Rožok (SE of Uličské Krivé village), old-growth beech forest, N48 $58^{\prime} 40-45^{\prime \prime} / \mathrm{E} 22^{\circ} 27^{\prime} 50^{\prime \prime}-28^{\prime} 10^{\prime \prime}$, Fs near a brooklet, 500$600 \mathrm{~m}, 2002$, leg. $A G, A L \& Z P$ (PRA); the valley of the Zbojský potok stream: upwards Nová Sedlica village, upstream, $F s, 680 \mathrm{~m}, 2002$, leg. $A L \& A G$.

Opegrapha vulgata Ach.

SPECIMENS EXAMINED: NNR Stužica: fir-beech forest in the valley of Stužická rieka, N4904'30-45"/E22³1'20”-22³2', Acps, 700-740 m, 2002, leg. AG \& ZP (PRA); ibid., the valley of the Stužická rieka river, the upper part, below the place called „Antošova lúka“, $A a, 700 \mathrm{~m}, 1989$, leg. IP; the valley of the Zbojský potok stream: upwards Nová Sedlica village, the meadow „Lúka Medovej baby“, young ash grow, Fr, $550 \mathrm{~m}, 2003$, leg. $A G \& A L$.

Parmelia submontana Nádv. ex Hale

SPECIMENS EXAMINED: NNR Jarabá skala: Riaba skala Mt., below the ridge, $A c$, $950 \mathrm{~m}, 1992$, leg. $A L \& I P$; ibid., the ridge, $A c p l$ (strongly leaning trunk), $1100 \mathrm{~m}$, 1992, leg. $A L \&$ IP; NNR Pl'aša: ridge below the summit, Fs (leaning trunk), 1100 m, 1992, leg. $A L \& I P$; NNR Stužica: well-lit beech forest below the ridge, between points Čiert'až and Hrúbky, N4905’30"/E22³1'30”, Acps, 1100 m, 2002, leg. AG \& 
ZP (PRA); NR Udava: spring area of the Udava river, Acps (leaning trunk), $720 \mathrm{~m}$, 1994, leg. $A L \& I P$; the valley of the Zbojský potok stream: upwards Nová Sedlica village, $F r, 700-800 \mathrm{~m}, 2002$, leg. $A G \& A L$.

Peltigera polydactylon (Neck.) Hoffm.

SPECIMEN EXAMINED: Ruská kotlina basin: abandoned village Ruské, the hill S of the Ruský potok river, $B$ (basis), $550 \mathrm{~m}, 1994$, leg. $A L \& I P$.

Peltigera rufescens (Weiss) Humb.

SPECIMENS EXAMINED: Oreničova skala place ( $\mathrm{S}$ of NNR Pl'aša): bryophytes over sandstone rocks, $710 \mathrm{~m}, 1994$, leg. $A L \& I P$; Ruská kotlina basin: abandoned village Ruské, the hill S of the Ruský potok river, arenaceous soil, $550 \mathrm{~m}, 1994$, leg. AL \& IP.

Pertusaria coccodes (Ach.) Nyl.

SPECIMENS EXAMINED: NNR Pl'aša: W-NW slope, deciduous forest in a spring area, $\mathrm{N}^{\circ} 06.90^{\prime} / \mathrm{E} 22^{\circ} 23.85^{\prime}$, Fs, $1127 \mathrm{~m}, 2004$, leg. ZP (PRA); NR Udava: spring area of the Udava river, Acps, $720 \mathrm{~m}, 1994$, leg. AL \& IP.

Pertusaria coronata (Ach.) Th. Fr.

Specimen EXAmined: NNR Jarabá skala: Riaba skala Mt., the top, $A c, 1150 \mathrm{~m}$, 1992, leg. $A L \& I P$.

Pertusaria hemisphaerica (Flörke) Erichs.

SPECIMEN EXAMINED: NNR Stužica: the valley of the stream Stužická rieka, mixed old-growth forest, Fs, 700-740 m, 2002, leg. $A G \& Z P$.

Pertusaria pertusa (Weigel) Tuck.

SPecimens EXAmined: NR Śípková: Acps, $970 \mathrm{~m}, 1992$, leg. $A L \&$ IP; NNR Jarabá skala: Riaba skala Mt., below the ridge, $F s, 900 \mathrm{~m}, 1992$, leg. $A L \& I P$.

Phaeophyscia chloantha (Ach.) Moberg

SPECIMEN EXAMINED: NNR Stužica: vrchol Čiert'aže, Fs, 1050 m, 1989, leg. IP.

Phaeophyscia endophoenicea (Harm.) Moberg

SPECIMENS EXAMINED: Kolbasov village (in the Ulička river valley): alder-grow on the bank of the Ulička stream, $S, 330 \mathrm{~m}, 1993$, leg. IP; NNR Pl'aša: Pl'aša Mt., S slope, Fs, $1130 \mathrm{~m}, 1992$, leg. $A L \& I P$; Part Nastaz: the valley of the Ublianka stream (NW of od Kalná Roztoka village): Acc, 450 m, 1993, leg. IP; the valley of the Zbojský potok stream: upwards Nová Sedlica village, open meadow, $F r, 440$ m, 2003, leg. $A G \& A L$; Uličská kotlina basin: Uličské Krivé village, managed beech forest ca 2 km E, N48 59'15-25"/E22²8', Fs, 500-550 m, 2002, leg. $A G, A L \& Z P$ (PRA).

Phaeophyscia pusilloides (Zahlbr.) Essl.

SPecimens eXAMined: NNR Stužica: Kamenná lúka Mt., Fs, 1150 m, 1989, leg. IP; the valley of the Zbojský potok stream: upwards Nová Sedlica village, the meadow „Lúka Medovej baby“, young ash grow, $F r, 550$ m, 2003, leg. $A G \& A L$.

!Porina aenea (Wallr.) Zahlbr.

SPeCimen EXAMINED: The valley of the Zbojský potok stream: upwards Nová Sedlica village, a stand with young Fraxinus and Alnus trees, $F r, 460$ m, 2003, leg. $A G \&$ $A L$.

Porina chlorotica (Ach.) Müll. Arg.

SPecimens EXAmined: Part Javorník: NNR Rožok (SE of Uličské Krivé village), E part of the reserve, on the rock by the stream, $340-400 \mathrm{~m}, 2002$, leg. $A G, A L \& Z P$; 
ibid., old-growth beech forest, N48 58'40-45"/E22²7'50"-28'10”, sandstone stones, 500-600 m, 2002, leg. $A G, A L \& Z P$ (PRA).

Ramalina fastigiata (Pers.) Ach.

SPECIMEN EXAMINED: Topol'a village (in the Ulička river valley): yard on a hill around orthodox wooden church, N49 $02.68^{\prime} / \mathrm{E}^{\circ} 2^{\circ} 21.39^{\prime}$, Acps, $^{\circ} 35 \mathrm{~m}, 2004$, leg. ZP \& J. Šárová (PRA).

Ramalina fraxinea (L.) Ach.

Specimen EXAMINED: Part Nastaz: valley $\mathrm{N}$ of Kalná Roztoka village, Fre, $350 \mathrm{~m}$, 1993, leg. AL \& IP.

Rhizocarpon distinctum Th. Fr.

SPECIMEN EXAMINED: NNR Jarabá skala: Riaba skala Mt., S slope, sandstone rocks, $1130 \mathrm{~m}$, 1992, leg. IP.

Rhizocarpon geminatum Körb.

SPECIMEN EXAMINED: NNR Jarabá skala: Riaba skala Mt., S slope, sandstone rocks, $1130 \mathrm{~m}, 1992$, leg. IP.

\section{!!Rinodina efflorescens Malme}

SPECIMEN EXAMINED: Topol'a village (in the Ulička river valley): yard on a hill around orthodox wooden church, N4902.68'/E22²1.39', Acps, 395 m, 2004, leg. ZP \& J. Šárová (PRA).

\section{Ropalospora viridis (Tønsberg) Tønsberg}

SPECimens EXAmined: Kolbasov village (in the Ulička river valley): $\mathrm{S}$ of the village, Ali, $330 \mathrm{~m}, 1993$, leg. IP; the valley of the Zbojský potok stream: upwards Nová Sedlica village, Alnetum incanae downstream, Ali, $470 \mathrm{~m}, 2003$, leg. $A G \& A L$; ibid., stand with young Fraxinus and Alnus trees, $A l, 460 \mathrm{~m}, 2002$, leg. $A G \& A L$; NNR Pl'aša: Pl'aša Mt., WNW slope, beech forest, N4907.18‘/E22²3.51‘, Fs, 942 m, 2004, leg. ZP (PRA).

!Sarcosagium campestre (Fr.) Poetsch \& Schied.

SPECIMEN EXAMINED: Part Javorník: NNR Rožok (SE of Uličské Krivé village), lowermost part, old-growth beech forest, N48 58'50-55"/E22²7’35-40”, Fs, 450-470 m, 2002, leg. $A G, A L \& Z P$ (PRA).

!Scoliciosporum umbrinum (Ach.) Arnold

SPECIMEN EXAMINED: The valley of the Zbojský potok stream: upwards Nová Sedlica village, mouth of the valley, open meadow, $F r, 440 \mathrm{~m}, 2003$, leg. AG\& AL.

Strigula stigmatella (Ach.) R.C. Harris

SPECIMENS EXAMINED: NNR Stužica: fir-beech forest in the valley of Stužická rieka, N4904'30-45"/E22³1'20”-22³2', Fs, 700-740 m, 2002, leg. AG \& ZP (PRA); ibid., fir-beech forest in steep slope, N49 04'15-20"/E22'32'15-20”, on sandstone pebbles, 750 m, 2002, leg. $A G \&$ \&P (PRA); Part Javorník: NNR Rožok (SE of Uličské Krivé village), old-growth beech forest, N48 58'50-55"/E22 $27 ’ 35-40 ”$, over mosses on $F s$ trunk, 470-480 m, 2002, leg. $A G, A L \& Z P$ (PRA).

Tephromela grumosa (Pers.) Hafellner \& Cl. Roux

SPECIMEN EXAMINED: NNR Pl'aša: sandstone rock on the top, $1160 \mathrm{~m}, 1992$, leg. $A L \& I P$. 
Thelocarpon laureri (Flot.) Nyl.

SPECIMENS EXAMINED: Ruská kotlina basin: the road between Ruské sedlo mountain pass $\mathrm{N}$ of the abandoned Ruské village, bare wood, $600 \mathrm{~m}, 1992$, leg. AL \& IP; Part Vel'ký Bukovec: Ruský Potok village, wooden fence, 400 m, 1993, leg. IP.

Thelotrema lepadinum (Ach.) Ach.

SPECIMEN EXAMINED: NNR Stužica: fir-beech forest in the valley of Stužická rieka, N4904'30-45”/E22³1'20”-2232', Fs, 700-740 m, 2002, leg. AG \& ZP (PRA).

!Thrombium epigaeum (Pers.) Wallr.

SPECIMEN EXAMINED: Sedlická kotlina basin: Nová Sedlica village, N4903'15-20”/ E22 31 '10", in ditch at roadside near the field station of NP Poloniny, on sandy soil, $450 \mathrm{~m}, 2002$, leg. ZP (PRA).

!Trapelia corticola Coppins \& P. James

Specimens eXAmined: NNR Stužica: Kremenec Mt., SW slope, fir-beech forest, along Kamenistý potok brook, N49 $05^{\prime} / \mathrm{E} 22^{\circ} 33^{\prime}$, rotten wood and of $A a, 900$ m, 2004, leg. ZP \& J. Šárová (PRA); ibid., dry wood, 900 m, 2002, leg. $A G \& Z P$ (PRA).

Trapelia glebulosa (Sm.) J.R. Laundon [= T. involuta, sec. Laundon 2005]

SPECIMEN EXAMINED: Nová Sedlica village: mountain pass "Sedlo pod Čiert'ažou", N4905'/E22`31', sandstone, 1100 m, 2004, leg. ZP \& J. Śárová (PRA).

\section{!Verrucaria dolosa Hepp}

Specimens exAmined: Sedlická kotlina basin: Nová Sedlica village, N4903'15$20 " / E 22^{\circ} 31 ' 10 "$, in ditch at roadside near the field station of NP Poloniny, sandstone pebble, 450 m, 2002, leg. ZP (PRA); Part Javorník: NNR Rožok (SE of Uličské Krivé village), a crest NE of the reserve, $48^{\circ} 588^{\prime} 50-55^{\prime} / \mathrm{E} 22^{\circ} 28^{\prime} 30^{\prime \prime}$, sandstone pebble, 750 m, 2002, leg. $A G, A L \& Z P$ (PRA).

!Vezdaea aestivalis (Ohl.) Tscherm.-Woess \& Poelt

SPECIMEN EXAMINED: NNR Stužica: fir-beech forest in the valley of Stužická rieka, N4904'30-45”/E22³1'20”-22³2', Fs, 700-740 m, 2002, leg. AG \& ZP (PRA).

The list reports and documents the most interesting findings of 100 lichens from Bukovské vrchy Mts (mostly from the small scale protected areas - National Nature Reserves and National Reserves), two of which are new for Slovakia and 34 new for the Bukovské vrchy Mts.

Several findings are interesting from ecological viewpoint. Agonimia repleta, obligatorily growing as an epiphyte, but recorded also on a clayey soil (Czarnota 2003), was found on sandstone pebbles in the studied area. An epiphyte Strigula stigmatella was also once recorded on sandstone pebble here. Similarly, Gyalecta ulmi, was collected in Bukovské vrchy Mts on dead bryophytes on a sandstone boulder. There are more records of this species from limestone or lime containing rocks in Slovakia, e.g. from Bachureň Mts., Branisko Mts., Kysucká vrchovina Mts, Pieniny Mts or Tatry Mts (Lackovičová, Guttová 2006). Belonia herculina, collected mostly in the Carpathians - apart from outlying localities in Slovenia and Caucasus (Arup et al. 2001; Otte 2004), was reported only from beech in Slovakia. Now it was collected on Acer pseudoplatanus. A second specimen from A.pseudoplatanus was found during revision of the material kept in BRA (Nízke Tatry Mts, Latiborská hol'a, 1200 m, 1972, leg. Vězda, BRA; not published so far). 
Brief comments on the novelties for Slovakia:

Fellhanera gyrophorica - a recently described corticolous species with similar appearance to Micarea pycnidiophora Coppins \& P. James. It has been so far reported from Central and Eastern European countries, including neighbouring Ukrainian Carpathians (Kostrino, Zhornava). It appears to be confined to well-preserved, oldgrowth/pristine broad-leaved forests (Sérusiaux et al. 2001; Czyżewska et al. 2001, 2005; Motiejūnaitè, Prigodina-Lukošienè 2002).

Rinodina efflorescens - a sorediate corticolous, mild-temperate species of humid woodlands and parklands in Scandinavia, British Isles, Central Europe, the Pyrénées and North America (Mayrhofer, Moberg 2002; Nimis 2003).

Acknowledgements: We thank to Prof. K. Czyżewska for comments on the manuscript and for Polish abstract. Z.P. thanks his wife Jana Palicová (Šárová) for help with collecting lichens in the field.

This work was supported by Slovak Research and Development Agency (No. APVV-51-040805), Grant Agency VEGA (No. 2/7068/27), Grant Agency of the Czech Republic (No. 206/03/1214) and Ministry of Education, Youth and Sports of the Czech Republic (No. 0021620828).

\section{REFERENCES}

Arup U., Wilfling L., Prügger J., Mayrhofer H. 2001. Contributions to the lichen flora of Slovenia VIII. Lichenized and lichenicolous fungi from Veliki Sneznik. (In:) P.M. McCarthy, G. Kantvilas, S.H.J.J. Louw hoff (eds). Lichenological Contributions in Honour of Jack Elix. Bibliotheca Lichenologica 78. J. Cramer, Berlin, Stuttgart.

Coppins B.J., Kondratyuk S.Ya., Khodosovtsev A.Ye., Zelenko S.D., Coppins A.M., Wolseley P.A., Virchenko V.M. 1998. Diversity of lichens and bryophytes in Regional Landscape Park „Stuzhytzia“ (Ukrainian part of the International Biosphere Reserve „Eastern Carpathians"). (In:) S.Ya. Kondratyu k, B.J. Coppins (eds). Lobarion lichens as indicators of the primeval forests of the Eastern Carpathians. M.H. Kholodny Institute of Botany, Kiev, Kostrino: $139-161$.

Coppins B.J., Kondratyuk S.Ya., Khodosovtsev A.Ye., Zelenko S.D., Wolseley P.A. 2005. Contribution to lichen flora of Ukrainian Carpathians. Chornomor. Botan. J. 1 (2): 5-23.

Czar n ot a P. 2003. Notes on some new and noteworthy lichens from southern Poland. Graphis Scripta 14: $18-26$.

Czyżewska K., Motiejūnaitè J., Cieśliński S. 2001. Species of lichenized and allied fungi new to Białowieża Large Forest (NE Poland). Acta Mycol. 36 (1): 13-19.

Czyżewska K., Motiejūnaitė J., Cieśliński S. 2005. New and noteworthy species of lichens and allied fungi from North-Eastern Poland. Acta Mycol. 40 (2): 277-291.

Gu t tová A. 1997. Príspevok k poznaniu lichenizovaných askomycét slovenskej časti Východných Karpát [Contribution to the distribution of lichenized ascomycetes in Eastern Carpathians within the territory of Slovakia]. Bull. Slov. Bot. Spoločn. 19: 78-83.

H a felln e r J., T ürk R. 2001. Die lichenisierten Pilze Österreichs - eine Checkliste der bisher nachgewiesenen Arten mit Verbreitungsangaben. Stapfia 76: 1-167.

Kiszk a J. 1997. Nowe i rzadkie gatunki porostów (Lichenes) w Bieszczadzkim Parku Narodowym. Cz. I. Roczniki Bieszczadzkie 5 (1996): 43-48.

Kiszk a J. 1999. Nowe i rzadkie gatunki porostów (Lichenes) w Bieszczadzkim Parku Narodowym i jego otulinie. Cz. II. Roczniki Bieszczadzkie 7 (1998): 343-347.

Kiszk a J., Kościelniak R. 1998. Lista florstyczna porostów polskich Karpat Wschodnich. Roczniki Bieszczadzkie 6 (1997): 49-63.

Kiszk a J., Koście ln iak R. 2001. Nowe i rzadkie gatunki porostów (Lichenes) w Bieszczadzkim Parku Narodowym i jego otulinie. Cz. III. Roczniki Bieszczadzkie 9 (2000): 27-32.

Kondratyuk S.Ya., Popova L.P., La ckovičová A., Pišút I. 2003. A catalogue of the Eastern Carpathian lichens. M.H. Kholodny Institute of Botany, Kiev, Institute of Botany, Bratislava, 263 pp.

Lackovičová A. 1998. Nové lokality pozoruhodných lišajníkov v chránených územiach Slovenska. Ochrana prírody, Banská Bystrica 16: 25-30. 
Lackovičová A., Guttová A. 2006. Lichen diversity - history, contemporary occurrence and trend in Slovakia: Gyalecta ulmi and Leptogium saturninum. (In:) A. Lackovičová, A. Guttová, E. Lisická, P. Lizoň (eds). Central European lichens - diversity and trends: 219-240. Mycotaxon.

La und on J.R. 2005. The publication and typification of Sir James Edward Smith's lichens in English Botany. Botanical Journal of the Linnean Society 147: 483-499.

Lišk a J. 1980. Doplňky k rozšîření některých lišejníků v ČSSR [Nachträge zur Verbreitung einiger Flechten in der Tschechoslowakei]. Zprávy Českosl. Bot. Společn. Čs. Akad. Věd. 15: 73-78.

Mayrhofer H., Moberg R. 2002. Rinodina. (In:) T. Ahti, P.M. Jørgensen, H. Kristinsson, R. Moberg, U. Søchting, G. Thor (eds). Nordic Lichen Flora, 2, Physciaceae: 41-69.

Motiejūnaitè J., Prigodin a-Lukošie nè I. 2002. Chaenothecopsis rubescens new to Lithuania and Fellhanera gyrophorica new to Estonia. Graphis Scripta 13: 43-44.

Nim is P.L. 2003. Checklist of the lichens of Italy 3.0. University of Trieste, Dept. of Biology, IN3.0/2 (http://dbiodbs.univ.trieste.it/).

Ot te V. 2004. Flechten, Moose und lichenicole Pilze aus dem nordwestlichen Kaukasus - erster Nachtrag. Feddes Repertorium 115: 155-163.

Pišú t I. 1963. Príspevok k poznaniu lišajníkov Slovenska III. Acta Fac. Rerum Nat. Univ. Comenianae, Bot. 8: 359-364.

Pišút I. 1966. Doplnky k poznaniu lišajníkov Slovenska 4. Nachträge zur Kenntnis der Flechten der Slowakei. Acta Rer. Natur. Mus. Nat. Slov. Bratislava 12: 57-61.

Pišút I. 1995. Zaujímavejšie nálezy lišajníkov zo Slovenska [Interessantere Flechtenfunde aus der Slowakei] 2. Bull. Slov. Bot. Spoločn. 17: 139-142.

Pišú t I., Lackovičová A. 1992. Flechten der Staatlichen Natur- Reservation Stužica (Gebirge Bukovské vrchy, Ostslowakei). Biológia, Bratislava, 47: 549-559.

Pišút I., Lackovičová A., Lisická E. 1996. A second checklist and bibliography of Slovak lichens. Biologia, Bratislava, 51/Suppl. 3: 1-79.

Pišút I., Gut tová A., La ckovičová A., Lisická E. 1998. Lichenizované huby (lišajníky) (Lichenforming fungi (lichens)). (In:) K. Marhold, F. Hindák (eds). Zoznam nižších a vyšších rastlín Slovenska (Checklist of non-vascular and vascular plants of Slovakia). Veda, Bratislava:229-295.

Poelt J. 1962. Bestimmungsschlüssel der höherer Flechten von Europa. Mitt. Bot. Staatssamml. München 4: 301-571.

Poelt J. 1969. Bestimmungsschlüssel europäischer Flechten. J. Cramer, Lehre.

Printzen C. 2004. Biatora. (In:) T.H. Nash III, B.D. Ryan, P. Diederich, C. Gries \& F. Bungartz (eds). Lichen Flora of the Greater Sonoran Desert Region. 2: 38-39.

Sérusiaux E., Coppins B.J., Die derich P., Scheidegger C. 2001. Fellhanera gyrophorica, a new European species with conspicuous pycnidia. Lichenologist 33: 285-289.

Servít M., Nádvorník J. 1935. Flechten aus der Čechoslovakei. V. Karpathorussland. Věstn. Král. Čes. Společn. Nauk Tř. Mat.-Přír. 1935: 1-34.

\section{Nowe dane o porostach z gór Bukowské vrchy (Słowacja Północno-Wschodnia)}

\section{Streszczenie}

W pracy przedstawiono 100 gatunków porostów z gór Bukovské vrchy, słowackiej części międzynarodowego, polsko-słowacko-ukraińskiego rezerwatu biosfery „Karpaty Wschodnie”, znanej jako Park Narodowy Połoniny.

Spośród prezentowanych porostów 34 gatunki są publikowane po raz pierwszy z badanego obszaru (!); dwa z nich: Fellhanera gyrophorica i Rinodina efflorescens to jednocześnie taksony nowe dla Słowacji (!!). Dla pozostałych 66 gatunków podano nowe stanowiska.

$\mathrm{Na}$ uwagę zasługują nowe dane ekologiczne odnoszące się do gatunków uważanych za obligatoryjne epifity, mianowicie Agonimia repleta (tylko okazjonalnie na gliniastej glebie) i Strigula stigmatella rosną tutaj na otoczakach piaskowcowych, a Gyalecta ulmi - na obumarłych mszakach zasiedlających piaskowcowe bloki skalne. 